\title{
The Effects of Gender Diversity in The Boardroom on Firm Financial Performance in Indonesia
}

\author{
Ayu Denisa Linggih ${ }^{1}$ \\ IGB Wiksuana ${ }^{2}$ \\ ${ }^{2}$ Post Graduate Program of Udayana University, Bali, Indonesia \\ Corresponding Author: Ayu Denisa Linggih
}

\begin{abstract}
This research investigates the effects of gender diversity in the boardroom on firm financial performance in Indonesia. To achieve the objective of this study, panel data analysis and fixed effects estimators have been applied to companies listed in Indonesia Stock Exchange in 2014 until 2016. The result of this study indicates that the percentage of women in the boardroom (board of commissioners and board of directors) has a significant positive effect on the company's financial performance as measured by return on assets $(R O A)$. The relationship between these variables is then explained by agency theory where increasing the percentage of women in the boardroom improves the supervision of the company's agents which in return will positively affect the financial performance of the company. The managerial implications and suggestions of this research are that companies should begin to empower more women in the company's top management, also the government should consider a minimum quota policy for women on board of commissioners and directors in Indonesia.
\end{abstract}

Keywords: Gender Diversity, Return on Assets, Financial Performance

ABSTRAK

Penelitian ini menyelidiki pengaruh keragaman gender di ruang dewan direksi terhadap kinerja keuangan perusahaan di Indonesia. Untuk mencapai tujuan penelitian ini, analisis data panel dan penduga efek tetap telah diterapkan pada perusahaan yang terdaftar di Bursa Efek Indonesia pada tahun 2014 hingga 2016. Hasil penelitian ini menunjukkan bahwa persentase wanita di ruang dewan (dewan komisaris dan dewan direksi) of directors) memiliki pengaruh positif yang signifikan terhadap kinerja keuangan perusahaan yang diukur dengan pengembalian atas aset (ROA). Hubungan antara variabel-variabel ini kemudian dijelaskan oleh teori agensi di mana peningkatan persentase wanita di ruang dewan meningkatkan pengawasan agen-agen perusahaan yang pada gilirannya akan secara positif mempengaruhi kinerja keuangan perusahaan. Implikasi manajerial dan saran dari penelitian ini adalah bahwa perusahaan harus mulai memberdayakan lebih banyak perempuan dalam manajemen puncak perusahaan, juga pemerintah harus mempertimbangkan kebijakan kuota minimum untuk perempuan di dewan komisaris dan direktur di Indonesia.

\section{Kata kunci: Keanekaragaman Gender, Pengembalian Aset, Kinerja Keuangan}

\section{Introduction}

One of the most important factors that determine the success of a company is its corporate governance. Good corporate governance will guide and control the company to reach their goals and achieve long-term success. Involving gender diversity in the boardroom has been considered as an implementation of good corporate governance because of the potential benefits it could bring to the company. In the present era, problems faced by companies are increasingly complex, and it needs the integration of diversity to improve the quality of the company's decision-making process. In his study Maznevski (1994) concluded that the heterogeneity within the company would improve the performance of the company. However, previous studies throughout different countries have shown inconclusive outcomes. Low et al. (2015) and Luckerath-Rovers (2013) found that women increases company's ability to raise profits through mitigating agency problem by increasing supervision, on the other hand, Adams and Ferreira (2009) believe gender diversity slow down the decision making process due to the lack of good cooperation between men and women. In addition, diversity in upper management can lead to conflict, decline in-group cohesiveness, and decrease in corporate value (Herring, 2009) 
Despite the contradictive opinion regarding this issue, some countries (i.e. Norway, France, Belgium) had taken steps forward imposing a minimum quota policy for women on board while some others have campaigns to narrow the gap (i.e. 2020 in the United States). Globally, there is a high percentage gap between men and women in the boardroom. Based on a report by Deloitte in 2017 , by 2015 the number of women in boardroom reached $12 \%$ and slightly increased to $15 \%$ by 2017 . The small increase indicates a lack of awareness in gender diversity inclusion on board, and can also due to low boardroom turnover.

According to Deloitte report (2017), Indonesia has female workers who account for $38 \%$ of 120 million people. The number of female workers in Indonesia is very huge when compared to neighboring countries such as Malaysia and Singapore, but the percentage of women in the Indonesian company's boardroom far below the two. In 2013, the percentages of women on board in Singapore and Malaysia respectively $10 \%$ and $14 \%$, while Indonesia it only reached $6,2 \%$. Until today, there is neither government policy nor campaigns to increase the percentage of women $n$ the board of commissioners and directors as been done by Norway, Belgium, Britain, France and the United States. In order to respond correctly to the increasing world trend of gender diversity in boardroom, it is important to investigate the effect on firm financial performance in Indonesia. Interestingly, the number of gender diversity on board in Indonesia has been increased each year until 2016, though there is a decline in companies' performance as measured by return on assets in the year 2015 and 2016. Therefore, this research on gender diversity in boardroom effects on firm financial performance will include other factors as controlling variables.

\section{Literature Review}

Corporate Governance

The concept of good corporate governance was first reviewed by Cadbury Committee in 1992 in Cadbury Report.Good corporate governance (GCG) is a principle that directs and controls the company to achieve a balance between the strength and authority of the company in providing accountability to the shareholders in particular, and stakeholders on generally. From the above definition can be concluded GCG is a system of rules, processes, corporate governance that regulate and control the company properly, it added value to the company.

\section{Corporate Governance in Indonesia}

Based on the General Guidelines of Good Corporate Governance of Indonesia in 2006 by the National Committee on Governance Policy, it is mentioned that one of the many reasons the multidimensional economic crisis hit Indonesia in 1998 is during that time most of Indonesian companies did not practice a consistent good corporate governance (GCG) and business ethics. In 1999, based on Decree of the Coordinating Minister of Economy Number: KEP / 31 / M.EKUIN / 08/1999, the National Committee on Corporate Governance Policy (KNKCG) was in form and issued the first GCG Guidelines. The GCG Guidelines have been refined several times, most recently in 2001. Based on the idea that a particular economic sector tends to have the same characteristics, in early 2004 the GCG Guidelines of Indonesian Banking was issued and in early 2006 issued the Guidelines of Indonesian Insurance GCG.

\section{Corporate Boardroom}

Boardroom consisting of General Meeting of Shareholders (AGMS), Board of Commissioners and Board of Directors, have an important role in the implementation of GCG effectively. Boardroom must perform its functions in accordance with the provisions applicable on the principle that each board has an independence in performing its duties, functions and responsibilities solely for the benefit of the company.

\section{Agency Theory}

This theory describes the relationship between the principal and the agent. An agent is someone who recruited the company and given the trust to run the company represent the principal whenthere is a separation of ownership and control of the company, agents or managers do not always act primarily interests of principal (shareholders). This theory raises the problems that can arise when the interests of principals and agents are opposed, and the agent chooses to do what he wants without being grounded in the idea that his actions are the 
Table 1.

Regression Analysis

\begin{tabular}{crrrr}
\hline Variable & Coefficient & Std. Error & t-Statistic & \multicolumn{1}{c}{ Prob. } \\
\hline WOMAN & 0.005687 & 0.002027 & 2.805515 & 0.0054 \\
FIRM SIZE & 0.002473 & 0.000986 & 2.507208 & 0.0128 \\
DEBT & -0.16455 & 0.023193 & -7.094774 & 0 \\
BOARDROOM SIZE & 0.054588 & 0.047025 & 1.160819 & 0.2468 \\
\hline
\end{tabular}

Source: Primary Data, 2018

best choice for the principal.

\section{Diversity Value}

Diversity in the work environment can increase the performance of the company or vice versa. Some researchers have argued about the presence or absence of a positive contribution of diversity to company performance. Reviewed by Herring (2009), overall diversity in the firm correlates with good corporate performance; as an example of increased sales, an increase in the number of consumers, and a larger market. LuckerathRovers (2013) and Low et al. (2015) mentioned that diversity increases performance through a more frequent board supervision, therefore agency problems can be reduced, and firm performance can be enhanced.

\section{Financial Performance}

Financial statements contain information about a company's finance. Firm financial performance can be evaluated through the information in the financial statement, since it reflects how well the company is dong in a certain period. With the existence of financial statements, leaders or management can see more clearly the company's financial condition based on actual data about the condition of the company. Financial performance can be analised using trend, historical data, and financial ratios.

\section{Hypotheses}

Gender diversity in the boardroom to firm financial performance

Research conducted by Mahadeo et al. (2012), Prihatiningtias (2012) and Ward \& Forker (2015) shown that there is a positive and significant correlation between gender diversity in the boardroom and the firm's financial performance as measured by return on assets. The positive relationship between gender diversity and return on assets is supported by agency theory which suggests that diversity in the boardroom better supervises managers because gender understanding increases the freedom of the board which then generates more incentives to oversee the running of enterprise management (Carter et al, 2007).

$\mathrm{H} 1$ : gender diversity in the boardroom positive and significant effect to firm financial performance.l

\section{Research Methods}

\section{Procedure}

The secondary data in this study were collected from the official website of the Indonesian Stock Exchange, the relevant books and journals. The population in this research is go-public companies that listed on the Indonesia Stock Exchange.The sample in this study are companies that are listed the Indonesia Stock Exchange within the period 2014 to 2016. We analised the data using panel data regression with fixed effect method.

Result

The value of companies' ROA is very varied and tend to be extreme. The same phenomenon occurs in variable percentage of women in the boardroom, where the average percentage of female presence ranges from 0.123 with standard deviation of 0.118 . This means there is considerable diversity in the percentage of women in each company, as evidenced by the minimum percentage of the number of women from 0.00 to a maximum of 0.55 . Data on firm size variables indicates homogeneity in data distribution. The debt ratio in each company shows a moderate diversity, as seen from the average score of 0.573 which is still higher than the standard deviation value of 0.246 . The minimum value in this variable is 0.04 while the maximum value is 1.92 .

In testing this hypothesis, the significant criteria is when the prob value obtained is less than 0.05 . Based on the table 1. below test results the probability of female values obtained is 0.0054 . Given this figure, it can be concluded that gender diversity in the boardroom has a significant positive effect on the firm's financial performance.

The prob score obtained for firm size is 0.0128 , it 
shows a significant positive relation between firm size to company return on assets. While the prob score obtained by debt is 0 with negative $t$ value, this number indicates that there is a significant negative relationship between debt with return on assets of company.

Unlike the other variables, the prob value on the board size is 0.2468 so it can be concluded that the number of boardroom members does not affect the performance of the company. All of the variables, the highest t-statistic value is owned by the female variable (the percentage of women in the boardroom). This figure shows that the influence of female variable to firm ROA is most dominant compared to other variables. This reflects the accuracy in selecting variables.

\begin{tabular}{ll}
\multicolumn{2}{c}{ Tabel 2. } \\
R-squared \\
\hline R-squared & 0.206745 \\
\hline Adjusted R-squared & 0.197149 \\
\hline S.E. of regression & 0.087527 \\
\hline Sum squared resid & 1.899920 \\
\hline Log likelihood & 258.2673 \\
\hline Durbin-Watson stat & 0.382498 \\
\hline Mean dependent var & 0.054781 \\
\hline S.D. dependent var & 0.097684 \\
\hline Akaike info criterion & -2.017994 \\
\hline Schwarz criterion & -1.961972 \\
\hline Hannan-Quinn criter. & -1.995452 \\
\hline Source: Primary Data, 2017
\end{tabular}

The adjusted R-Squared score of 0.20 indicates that the variables used in this study can account for as much as $20 \%$ of the effect on the financial performance of firms, of which $80 \%$ are influenced by other factors not included in the model. The R-Squared score result are presented in Table 2. above.

\section{Discussion and Conclusion}

The existence of gender diversity in the boardroom that the board of commissioners and directors bring a positive influence on the financial performance of companies in Indonesia as measured in return on assets ratio.Gender diversity has a positive effect on financial performance, because: 1) Improve the decision-making process between the board of commissioners and directors. 2) Improving the independence of the board of commissioners and directors, so that control and supervision of the company can be done more. Increased control and supervision on the performance of corporate agents will press agency problems from arising because of the different interest between the principal and agents as mentioned in agency theory.

Research Implication

The results of this study provide information that the presence of women in boardroom will improve the company's financial performance as measured by return on assets. Gender diversity brings added value in the boardroom by improving the quality of the decision-making process. Women with different experiences of life, work, and characteristics will add creativity of giving solutions so that the decision-making process can be improved as there are more things to be considered and evaluated.In addition, this phenomenon can be explained by agency theory. The existence of women increases boardroom independence, which results in more incentives to control and supervise manager's performance. This can lowerthe conflicts that arise from agency problems and can encourage corporate agents to improve their performance in obtaining profit for shareholders.

\section{Limitation and Future Research}

The results of this study have limitations that can be used as the next research, 1) This study investigates impact of gender diversity in the boardroom directly to financial performance without any mediation variables or other types of variables. It is suggested for future research regarding this topic, to use other variable for example financial decision as a mediating variable. 2) This study only investigates the relationship of gender diversity in the boardroom to the financial performance of the company using one independent variable, one dependent variable and three control variables with the result of low R-Squared value. Based on this limitation, future research is suggested to use more variables to increase the value of R-Squared.

\section{Reference}

Adams, R. B. \& Ferreira, D. 2009. Women in the boardroom and their impact on governance and performance. Journal of Financial Economics, Vol.94, pp.291-309.

Carter, D. A., D’Souza, F., Simkins, B. J. \& Simpson, W. G. 2010. The gender and ethnic diversity of US boards and board committees and firm financial performance. Corporate Governance: An International Review, Vol.18, No.5, pp.396414. 
Deloitte Global Center for Corporate Governance. 2017. Women in the Boardroom: A global Perspective (Online)

Herring, C. 2009. Does diversity pay?: Race, gender, and the business case for diversity. American Sociological Association, Vol.74, No.2, pp.208224.

Low, D., Roberts, H. \& Whiting, R. 2015. Board gender diversity and firm performance: Empirical evidence from Hong Kong, South Korea, Malaysia and Singapore. Pacific-Basin Finance Journal, Vol.35, pp.381-401

Luckerath-Rovers, M. 2013.Women on board and firm performance. Journal of Management \& Governance, Vol. 17, No. 2, pp 491-509

Mahadeo, J. D., Soobaroyen, T., \& Hanuman, O. 2012. Board Composition and Financial Performance: Uncovering the Effects of Diversity in an Emerging Economy. Journal of Business Ethics, Vol. 105, pp 375-388.

Maznevski, M.L. 1994. Understanding our differences: performance in decision-making groups with diverse members. Human Relations, Vol.47, pp.531-552.

Prihatiningtias, Y. W. 2012. "Gender diversity on the boardroom and firm performance: evidence from Indonesian publicly listed financial firms", Thesis, University of Canberra, Australia

Watson, W. E., Kumar, K. \& Michaelsen, L. K. 1993. Cultural diversity's impact on interaction process and performance: Comparing homogeneous and diverse task groups. Academy of Management, Vol.36, No.3. pp 590-622 